\title{
A NOTE ON UPPER OCEAN TEMPERATURE AND SALINITY AT THE ENTRANCE TO THE GULF OF CALIFORNIA IN AUGUST 1992
}

\section{UNA NOTA SOBRE LA TEMPERATURA Y SALINIDAD DE LA CAPA SUPERIOR DEL OCÉANO EN LA ENTRADA DEL GOLFO DE CALIFORNIA EN AGOSTO 1992}

\author{
Luis Felipe Navarro-Olache ${ }^{+}$ \\ $\Lambda$ ffonso S. Mascarenhas Jr. \\ Reginaldo Durazo ${ }^{++}$ \\ Curtis A. Collins' ${ }^{\prime+}$ \\ Instituto de Investigaciones Oceanológicas \\ Universidad Autónoma de Baja California \\ Apartado postal 453 \\ Ensenada, Bạja California, México
}

Recibido en septiembre de 1996; aceptado en febrero de 1997

\begin{abstract}
Fernández-Barajas et al. (1994) report results of hydrographic measurements at the entrance to the Gulf of California in August 1992. During this cruise, the CTD was improperly calibrated, and this resulted in anomalously high (low) near-surface temperatures (salinities) being reported. FernándezBarajas et al. (1994) incorrcctly attribute these anomalous surface conditions to the 1991-1993 El Niño and tropical storm Lester.
\end{abstract}

Key words: sea surface temperature, sea surface salinity, Gulf of California, El Niño.

\section{RESUMEN}

Fernández-Barajas et al. (1994) reportan los resultados de mediciones hidrográficas realizadas en la entrada del Golfo de California en agosto de 1992. Durante ese crucero, el CTD se encontraba calibrado inadecuadamente, teniendo como resultado mediciones anomalas de altas temperaturas y bajas salinidades. Fernández-Barajas et al. (1994) incorrectamente atribuyeron estas condiciones anómalas al fenómeno El Niño de 1991-1993 y a la tormenta tropical Lester.

Palabras clave: temperatura de la superficie del mar, salinidad de la superficie del mar, Golfo de California, El Niño.

Current address: Department of Oceanography, University of Southampton/SOC, European Way, Southampton, SO14 3ZI, United Kingdom.

++ Current address: Facultad de Ciencias Marinas, Universidad Autónoma de Baja California, km 106 carretera Tijuana-Fnsenada, Ensenada, Baja California, México.

${ }^{+++}$Current address: Department of Oceanography, 833 Dyer Road, Rm 328, Naval Postgraduate School, Monterey, CA 93943, USA. 


\section{BACKGROUND}

Results of hydrographic measurements at the entrance to the Gulf of California on the PALEO VI cruise in August 1992 (FernándezBarajas et al., 1994, hereafter called FB94) yield upper ocean conditions that appear odd: the surface layer was hot (temperature cqual to $\left.32.77^{\circ} \mathrm{C}\right)$, deep $(-25 \mathrm{~m})$ and vertically and horizontally homogeneous. The degree of homogeneity was remarkable, i.e., the observed temperature was $32.77^{\circ} \mathrm{C}$ for stations $1-7$, and for depths ranging from the surface to $17 \mathrm{~m}$ and to $27 \mathrm{~m}$. If correct, these conditions would be remarkable for an open ocean region, as generally SST does not exceed $29^{\circ} \mathrm{C}$ except in the surface microlayer. Although we know precious little about El Niño conditions along the coast of North America, the data that are available appear to show that El Niño is principally manifested by subsurface warming, probably associated with a deepening of the thermocline, with only modest surface warming (about $0.5^{\circ} \mathrm{C}$ ) (Cole and McLain, 1989). Within the Gulf of California, observations in Guaymas Basin (Robles and Marinone, 1987) indicated a deepening of the thermocline during the 1983 El Niño and a freshening of surface waters of about $\Delta \mathrm{S}=0.2$; surface waters also appeared $3^{\circ} \mathrm{C}$ warmer than normal in Guaymas Basin during March 1983, but this temperature difference disappeared by October 1983 (fig. $2 \mathrm{~g}$, Robles and Marinone, 1987).

\section{DISCUSSION}

The CTD used on the PALEO VI cruise was a Neil Brown Instrument System (NBIS) Mark IIIB, owned by the Universidad Nacional Autónoma de México and maintained by the R/V El Puma. Neither calibration records nor independent temperature observations are available for the CTD for the cruise. Note that the maximum temperature that this CTD can normally report is $32.767^{\circ} \mathrm{C}$ (EG\&G Ocean Products, 1982). Examination of the temperature records from the CTD indicate that this value, $32.767^{\circ} \mathrm{C}$, was recorded as follows (a chart of station positions is given in fig. 2):

\section{ANTECEDENTES}

Los resultados de mediciones hidrográficas realizadas en el crucero PALEO VI en agosto de 1992 en la entrada del Golfo de California (Fernández-Barajas et al., 1994, en adelante FB94) muestran condiciones raras en la capa supcrior del océano: la capa superficial estaba a temperatura alta $\left(32.77^{\circ} \mathrm{C}\right)$, profunda $(\sim 25 \mathrm{~m})$ y vertical $y$ horizontalmente homogénea. El grado de homogeneidad fue notable, i.e., la temperatura observada fue de $32.77^{\circ} \mathrm{C}$ para las estaciones 1-7, desde la superficie hasta $17 \mathrm{~m} \mathrm{y}$ $27 \mathrm{~m}$ de profundidad. Estas condiciones, de ser correctas, serían extraordinarias para una región de mar abierto, ya que la temperatura de la superficie del mar generalmente no excede a los $29^{\circ} \mathrm{C}$, excepto en la microcapa de la superficie. A pesar de que conocemos muy poco acerca de las condiciones de El Niño a lo largo de la costa de Norteamérica, los datos disponibles parecen indicar que El Niño se manifiesta principalmente a través del calentamiento del agua subsuperficial, probablemente asociado con el hundimiento de la termoclina, con poco calentamiento de la superficie (casi $0.5^{\circ} \mathrm{C}$ ) (Cole y McLain, 1989). Dentro del Golfo de California, observaciones en la Cuenca de Guaymas (Robles y Marinone, 1987) indicaron un hundimiento de la termoclina durante El Niño de 1983 y una disminución de salinidad en el agua superficial alrededor de $\Delta \mathrm{S}=0.2$; el agua superficial también pareció estar $3^{\circ} \mathrm{C}$ más caliente que lo normal en la Cuenca de Guaymas durante marzo de 1983, pero esta diferencia en temperatura desapareció para octubre de 1983 (fig. $2 \mathrm{~g}$, Robles y Marinone, 1987).

\section{DISCUSIÓN}

EI CTD utilizado en el crucero PALEO VI fue un Neil Brown Mark IIIB, de la Universidad Nacional Autónoma de México, a bordo del B/O El Puma. No hay registros de calibración ni observaciones independientes de temperatura para el CTD del crucero. Se debe notar que la temperatura máxima que este CTD normalmente puede registrar es $32.767^{\circ} \mathrm{C}$ (EG\&G Ocean Products, 1982). La revisión de 
station 1 to $24 \mathrm{~m}$, station 2 to $17 \mathrm{~m}$, station 3 to $25 \mathrm{~m}$, station 4 to $27 \mathrm{~m}$, station 5 to $26 \mathrm{~m}$, station 6 to $23 \mathrm{~m}$, station 7 to $24 \mathrm{~m}$. At station 8 , a 6 -m deep surface layer of temperature $31.95^{\circ} \mathrm{C}$ was recorded. Hence, it appears that the nearsurface values for this cruise exceeded the range of the CTD because the CTD was not in proper calibration.

To confirm this, we have examined the meteorological observations from the $\mathrm{R} / \mathrm{V} E l$ Puma's logs and archived nighttime multichannel sea surface temperature (MCSST). We also used a temperature-salinity (TS) curve derived from a recent cruise at the entrance to the gulf to try to estimate the correct temperature.

Meteorological observations (wind speed and direction, air temperature and barometric pressure) were logged by the ship's officers as part of their duties. Air temperatures during the cruise ranged from $25^{\circ} \mathrm{C}$ to $34^{\circ} \mathrm{C}$ and averaged $29^{\circ} \mathrm{C}$. The air temperatures varied diurnally, with mean minimum temperature, $26^{\circ} \mathrm{C}$, at 0400 and mean maximum temperature, $32^{\circ} \mathrm{C}$, at 1600 . Winds during the cruise were almost nonexistent, consisting of light airs (2-3 knots), and calm. The temperature of the air during the summer at these latitudes typically is a degree warmer during the day and a degree cooler during the evening than the sea surface. This pattern was also observed at the entrance to the gulf on El Puma in August 1995.

Studies of the climatology of the marine boundary layer have established a relationship between the air-sea temperature difference and the Bowen ratio (p. 254, Roll, 1965). The Bowen ratio computed from data for the northern gulf (Lavín and Organista, 1988) is -0.24 for summer. Using Roll's (1965) figure, this yields a sea surface temperature which is $0.5^{\circ} \mathrm{C}$ less than the air temperature, i.e., the sea surface temperature for the PALEO VI cruise should have averaged about $28.5^{\circ} \mathrm{C}$ in order to be consistent with climatological relationships.

We have also examined MCSST data for the two-week period of the PALEO VI cruise. The historical data have been composited for one-week periods with a horizontal resolution of $18 \mathrm{~km}$. The area along the ship's track los registros de temperatura del CTD indica que este valor, $32.767^{\circ} \mathrm{C}$, se registró de la siguiente manera (en la fig. 2 se muestra una gráfica de las posiciones de las estaciones): estación 1 hasta $24 \mathrm{~m}$, estación 2 hasta $17 \mathrm{~m}$, estación 3 hasta $25 \mathrm{~m}$, estación 4 hasta $27 \mathrm{~m}$, estación 5 hasta $26 \mathrm{~m}$, estación 6 hasta $23 \mathrm{~m}$, estación 7 hasta $24 \mathrm{~m}$. En la estación 8 , se registró una capa superficial de $6 \mathrm{~m}$ de profundidad con una temperatura de $31.95^{\circ} \mathrm{C}$, por lo que parece que los valores cercanos a la superficie para este crucero excedieron el intervalo del CTD porque estaba fuera de calibración.

Para confirmar esto, se han revisado las observaciones meteorológicas de la bitácora del B/O El Puma, así como imágenes nocturnas de multibanda de la temperatura de la superficie del mar (MCSST). También se usó una curva de temperatura y salinidad (TS) derivada de un crucero reciente a la entrada al golfo para tratar de estimar la temperatura correcta.

Los oficiales del barco, como parte de su trabajo, registraron las observaciones meteorológicas (rapidez y dirección del viento, temperatura del aire y presión barométrica). Las temperaturas del aire durante el crucero variaron desde $25^{\circ} \mathrm{C}$ hasta $34^{\circ} \mathrm{C}$, con un promedio de $29^{\circ} \mathrm{C}$. Las temperaturas del aire presentaron variación diurna, con una temperatura mínima media de $26^{\circ} \mathrm{C}$ a las 0400 y una temperatura máxima media de $32^{\circ} \mathrm{C}$ a las 1600 . Los vientos durante el crucero fueron de poca rapidez (2-3 nudos) o de calma. La temperatura del aire durante el verano en estas latitudes típicamente es un grado más caliente durante el día y un grado más frío durante la noche que la de la superficie del mar. Este patrón también se observó en la entrada del golfo a bordo de $E l$ Puma en agosto de 1995.

Estudios climatológicos de la capa atmosférica de frontera adyacente al océano han establecido una relación entre la diferencia en temperaturas aire-mar y la razón de Bowen (p. 254, Roll, 1965). la razón de Bowen calculada a partir de datos en el golfo norte (Lavín y Organista, 1988) es -0.24 para el verano. Si se utiliza el valor de Roll (1965), esto da una temperatura de la superficie del mar $0.5^{\circ} \mathrm{C}$ menor que la temperatura del aire, i.e., la temperatura 
contains only one or two values during this period of time, probably due to clouds. MCSST values ranged from $29^{\circ} \mathrm{C}$ to $30^{\circ} \mathrm{C}$.

Figure 1 shows mean TS curves for the region encompassing the entrance to the Gulf of California. The PESCAR TS curve is an average of that obtained along a section between Isla Cerralvo, Baja California Sur, and El Dorado, Sinaloa (PESCAR 7, August 1995). A Sea-Bird CTD was used on this cruise, with calibration done by the Naval Postgraduate School and Sea-Bird. Two TS curves are given for the PALEO VI cruise. One is the mean for stations $1-8$ as recorded by the CTD during the cruise, while the second was obtained from fig. $8 \mathrm{a}$ in FB94. The NBIS instrument appears to be badly out of calibration, with maximum salinities of $\mathrm{S}=35.5$ reported at depth and minimum salinities less than $\mathrm{S}=33$ reported near the surface. At the surface, the constant (maximum) temperatures create the appearance of a near-surface salinity minimum, but note that the density of the surface water exceeds that of the water at the salinity minimum, yet another indication that the instrument is badly out of calibration.

FB94 provide no details of how they corrected the CTD data. Figure 1 shows that FB94 modified deep salts (temperature less than $10^{\circ} \mathrm{C}$ ) to conform to climatological values. On the other hand, for temperatures greater than $15^{\circ} \mathrm{C}$, they appear to have used salinity values which were close to those given by the CTD.

The temperatures associated with the deep salinity minimum were $6.05^{\circ} \mathrm{C}$ for PESCAR data and $7.65^{\circ} \mathrm{C}$ for PALEO VI, a difference of $1.6^{\circ} \mathrm{C}$. The temperatures associated with the subsurface salinity maximum were $13.55^{\circ} \mathrm{C}$ for PESCAR and $15.55^{\circ} \mathrm{C}$ for PALEO VI, a difference of $2^{\circ} \mathrm{C}$. Averaging these temperature differences yields $1.8^{\circ} \mathrm{C}$. Extrapolating these values as a function of temperature to $32.7^{\circ} \mathrm{C}$ yields a difference of $2.9^{\circ} \mathrm{C}$.

A further examination of the recorded CTD data shows a temperature cycling that is especially noticeable at depth. Over a range of 2-3 dbar, the temperature will decrease by as much as $1.5^{\circ} \mathrm{C}$ in a single $30 \mathrm{~Hz}$ scan, then de la superficie del mar en el crucero PALEO VI debió haber tenido un promedio alrededor de $28.5^{\circ} \mathrm{C}$ para ser consistente con relaciones climatológicas.

También se han revisado datos del MCSST del periodo de dos semanas del crucero PALEO VI. Se agruparon los datos históricos en periodos de una semana con una resolución horizontal de $18 \mathrm{~km}$. El área a lo largo de la trayectoria del barco contiene solamente uno o dos valores para este periodo de tiempo, debido probablemente a la nubosidad. Los valores del MCSST variaron de $29^{\circ} \mathrm{C}$ a $30^{\circ} \mathrm{C}$.

La fig. 1 muestra las curvas TS medias para la región que comprende la entrada del Golfo de California. La curva TS de PESCAR es un promedio obtenido a lo largo de una sección entre la Isla Cerralvo, Baja California Sur, y El Dorado, Sinaloa (PESCAR 7, agosto de 1995). En este crucero se utilizó un CTD marca SeaBird, calibrado por la compañía Sea-Bird y la Naval Postgraduate School. Se presentan dos curvas TS para el crucero PALEO VI. Una es la media de las estaciones $1-8$, como fue registrado por el CTD durante el crucero, mientras que la segunda se obtuvo de la fig. 8a de FB94. Al parecer, el instrumento NBIS está fuera de calibración, por lo que registró salinidades máximas de $\mathrm{S}=35.5$ en aguas profundas y salinidades mínimas menores de $S=33$ cerca de la superficie. En la superficie, las temperaturas constantes (máximas) crean la apariencia de un mínimo de salinidad cercano a la superficie, pero hay que notar que la densidad del agua superficial excede la del agua con el mínimo de salinidad, lo que también indica que el instrumento estaba mal calibrado.

En FB94 no se indica como se corrigieron los datos del CTD. La fig. 1 señala que en FB94 se modificaron las sales profundas (temperaturas menores que $10^{\circ} \mathrm{C}$ ) para que se conformaran a valores climatológicos. Por otro lado, para las temperaturas mayores que $15^{\circ} \mathrm{C}$, parece ser que se utilizaron valores de salinidad que estaban cercanos a aquellos del CTD.

Las temperaturas asociadas con el mínimo de salinidad profundo fueron $6.05^{\circ} \mathrm{C}$ para los datos de PESCAR y $7.65^{\circ} \mathrm{C}$ para PALEO VI, 


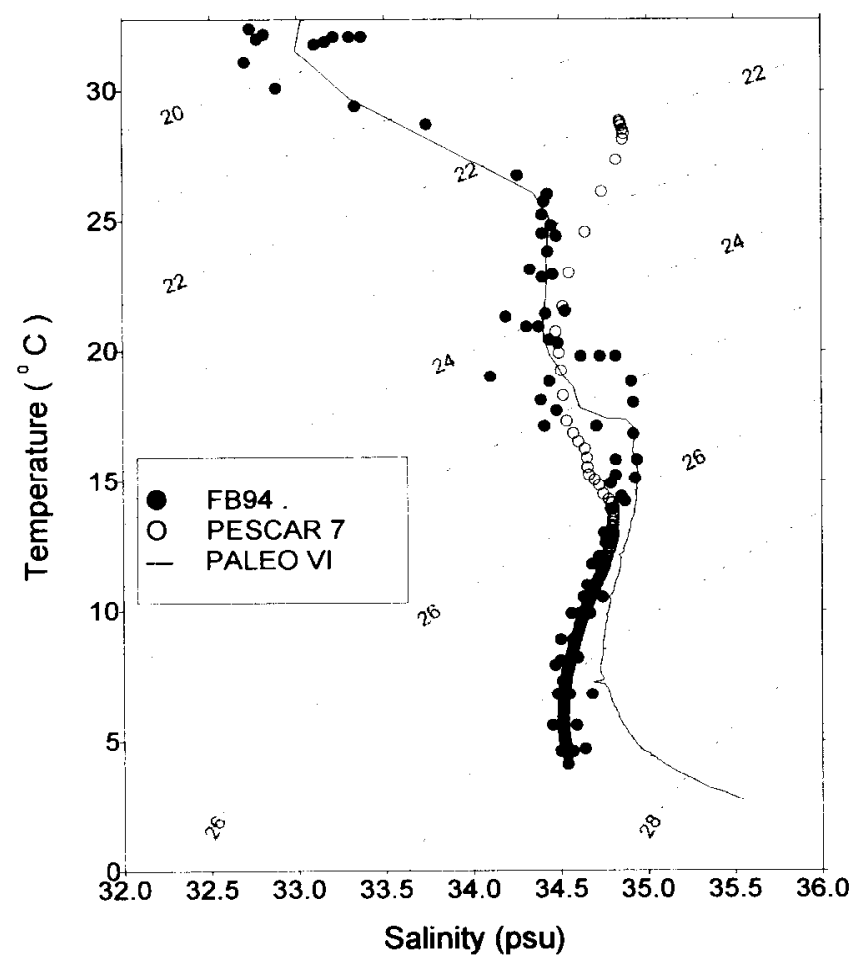

Figure 1. Temperature-salinity (T-S) relationship for waters at the entrance to the Gulf of California. The open circles indicate the mean derived from 16 CTD stations between Isla Cerralvo, Baja California Sur, and El Dorado, Sinaloa, performed in August 1995 (PESCAR 7). The solid line is an average for the CTD data from stations 1-8 on the PALEO VI cruise in August 1992. The black circles represent the T-S relationship given in fig. 8a of Fernández-Barajas et al. (1994) for these same stations; below $17^{\circ} \mathrm{C}$ their T-S relationship is approximately the same as that of the PESCAR 7 mean.

Figura 1. La relación entre temperatura y salinidad (T-S) para el agua en la entrada del Golfo de California. Los círculos abiertos indican la media derivada de 16 estaciones CTD entre la Isla Cerralvo, Baja California Sur, y El Dorado, Sinalua, en agosto de 1995 (PESCAR 7). La línea sólida es un promedio de los datos de las estaciones 1-8 en el crucero PALEO VI en agosto de 1992. Los círculos negros representan la relación T-S de la fig. 8a en Fernández-Barajas et al. (1994) para estas mismas estaciones; debajo de $17^{\circ} \mathrm{C}$ su relación T-S es aproximadamente la misma que la de la media de PESCAR 7.

increase slowly, so that within a second or so temperature is a maximum. While the temperature differences discussed above result from improper calibration, this behavior indicates that there were other problems with the CTD system.

FB94 report very low salinities for the upper layer in the lower gulf, salinities that are una diferencia de $1.6^{\circ} \mathrm{C}$. Las temperaturas asociadas con el máximo de salinidad subsuperficial fueron $13.55^{\circ} \mathrm{C}$ para PESCAR y $15.55^{\circ} \mathrm{C}$ para PALEO VI, una diferencia de $2^{\circ} \mathrm{C}$. El promedio de estas diferencias en temperatura es $1.8^{\circ} \mathrm{C}$. La extrapolación de estos valores, en función de la temperatura, a $32.7^{\circ} \mathrm{C}$ resulta en una diferencia de $2.9^{\circ} \mathrm{C}$. 
about $S=1$ less than the minimum salinity in the historical data record for these temperatures. (Note that the data record includes a cruise in August 1957 [Roden and Groves, 1959] during a major Et Niño cvent.) They hypothesizc that this is because a salinity front, normally found off Puerto Vallarta, has been advected into the gulf. They atso suggest that tropical storm Lester might have contributed to these low salinities.

The ocean response to tropical storms in the open ocean has been studied by a number of investigators (see Pudov and Holland, 1994), including tropical storm Norbert near Baja California in September 1984 (Sanford et al., 1987). Upper ocean changes were principally due to turbulent entrainment, increasing mixed layer depths as much as a factor of three. The cool water which was entrained into the mixed layer resulted in a reduction of sea surface temperature. In the case of Norbert, the maximum cooling observed was $-2.2^{\circ} \mathrm{C}$ and was associated with a mixed layer depth of $62 \mathrm{~m}$ (Sanford et al., 1987). Pudov and Holland (1994) report a complicated pattern of sea surface salinity changes of \pm 0.15 associated with tropical storms in the western Pacific.

In August 1995, observations were made at the entrance to the Gulf of California from El Puma, with a Sea-Bird 911 Plus CTD (Blanco-Betancourt et al., 1995), immediately after tropical storm Flossie. Figure 2 compares the storm tracks of Flossie and Lester and shows that Flossie passes much closer to the entrance to the gulf. The rainfall records from Cabo San Lucas, Baja California Sur, indicate a total rainfall of $32 \mathrm{~mm}$ for Lester, and from La Paz, $41.1 \mathrm{~mm}$ for August 1995 (Flossie). Figure 3 shows the upper ocean salinity tield from the August 1995 cruise: no freshening of surface waters was observed. Indeed, gulf water ( $\mathrm{S}>34.9$ ) appeared as a maximum at the surface in the center of the section and minimum sea surface salinity $(S=34.5)$ was observed at the Sinaloa coast. California Current waters were clearly seen as a subsurface salinity minimum at about $50 \mathrm{~m}$ depth. We conclude that tropical storm Lester cannot explain the freshening of surface waters reported by FB94.
Otra revisión de los datos del CTD registrados muestra una variación cíclica de temperatura que es especialmente notable en aguas profundas. En un intervalo de 2-3 dbar, la temperatura decrece hasta $1.5^{\circ} \mathrm{C}$ entre dos muestras sucesivas a $30 \mathrm{~Hz}$ y luego se incrementa lentamente, tal que dentro de aproximadamente un segundo, la temperatura es máxima. Mientras que las diferencias en temperatura discutidas arriba provienien de una mala calibración, este comportamiento indica que hubo otros problemas con el CTD.

FB94 reportan salinidades muy bajas para la capa superior en el bajo golfo, las cuales son alrededor de $\mathrm{S}=1$ menor que la salinidad mínima en el registro de datos históricos para estas temperaturas. (Nótese que el registro de datos incluye un crucero en agosto de 1957 [Roden y Groves, 1959] durante un evento E] Niño). FB94 suponen que esto se debe a que un frente halino, que normalmente se encuentra adyacente a Puerto Vallarta, ha sido desplazado hacia adentro del golfo. También sugieren que la tormenta tropical Lester pudo haber contribuido a estas salinidades bajas.

Varios investigadores (ver Pudov y Holland, 1994) han estudiado la respuesta del océano a tormentas tropicales en el mar abierto, incluyendo la tormenta tropical Norbert cerca de Baja California en septiembre de 1984 (Sanford et al., 1987). Los estudios sugieren que los cambios en la capa superior del océano se deben principalmente a un abordamicnto turbulento, el cual incrementa la profundidad de la capa de mezcla hasta un factor de tres. El agua fría que aborda a la capa de mezcla trae consigo una reducción en la temperatura de la superficie del mar. En el caso de Norbert, el enfriamento máximo observado fue de $-2.2^{\circ} \mathrm{C}$, el cual estuvo asociado con una profundidad de la capa de mezcla de $62 \mathrm{~m}$ (Sanford et al., 1987). Pudov y Holland (1994) reportan un patrón complejo de cambios de salinidad en la superficie del mar de \pm 0.15 , asociados con tormentas tropicales en el Pacífico occidental.

En agosto de 1995, se realizaron observaciones en la entrada del Golfo de California a bordo del B/O El Puma, con un CTD Sea-Bird 911 Plus (Blanco-Betancourt et al., 1995), 


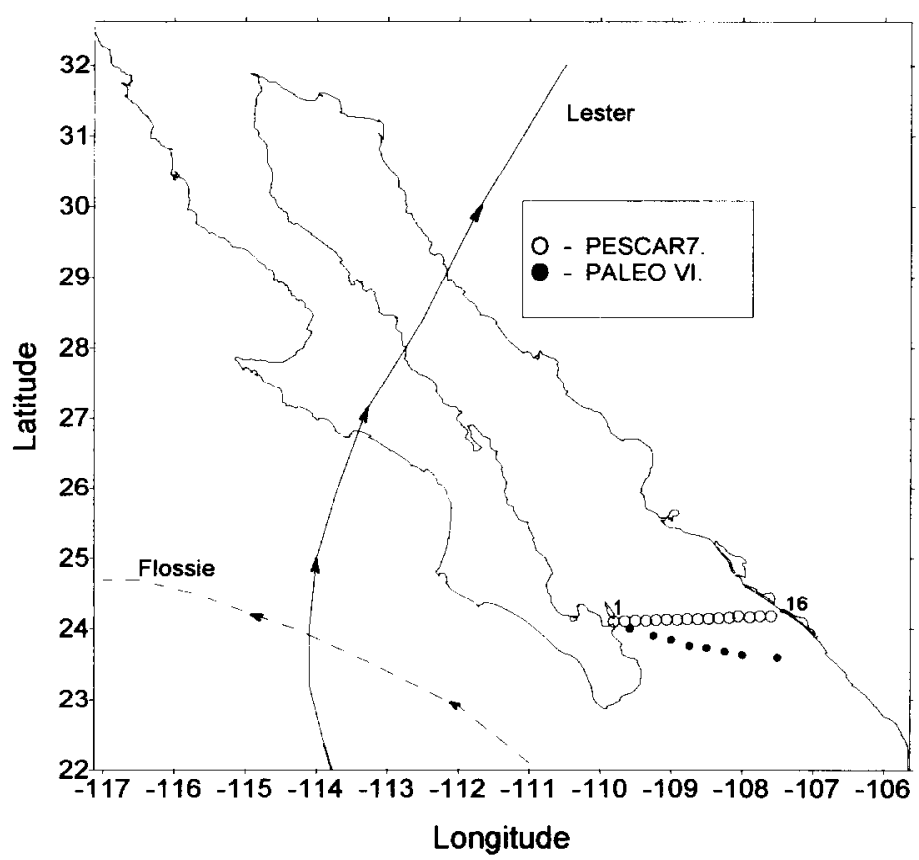

Figure 2. Ground tracks for hurricanes Lester (August 1992) and Flossie (August 1995). Also shown are station positions for PALEO VI leg 1 and PESCAR 7, stations 1-16.

Figura 2. Trayectorias de los huracanes Lester (agosto de 1992) y Flossie (agosto de 1995). También se señalan las posiciones de las estaciones en el transecto 1 del PALEO VI y las estaciones 1-16 de PESCAR 7.

As noted by FB94, the more likely source of warm, fresh waters at the entrance to the gulf were tropical surface waters (TSW). Climatological analyses of surface waters at the entrance to the gulf show that the mean salinity in August ranges from $S=34.4$ to $S=34.7$ from Sinaloa to Baja California Sur, respectively (López-Bojórquez, 1996). Volumetric analyses (Torres-Orozco, 1993) show TSW over the Sinaloa shelf in Pescadero Basin, especially in summer and fall. Note that some care should be taken in analyses of water properties in central and western Pescadero Basin, since a mixture of gulf and California Current waters can produce a temperature-salinity signature similar to that of TSW. To explain the observed freshening in Guaymas Basin, Robles and Marinone (1987) argue that TSW and California Current waters mix at the entrance to the gulf during El Niño inmediatamente después de la tormenta tropical Flossie. La fig. 2 compara las trayectorias de las tormentas Flossie y Lester y muestra que Flossie pasa más cerca de la entrada del golfo. Los registros de precipitación para Cabo San Lucas, Baja California Sur, indican una precipitación total de $32 \mathrm{~mm}$ para Lester y en La Paz de $41.1 \mathrm{~mm}$ en agosto de 1995 (Flossie). La fig. 3 presenta el campo de salinidad de la capa superior del océano durante el crucero en agosto de 1995: no se observa una disminución de salinidad en el agua superficial. De hecho, el agua del golfo $(S>34.9)$ aparece en la figura como un máximo en la superficie en el centro de la sección y se observa una salinidad mínima en la superficie del mar $(S=34.5)$ a lo largo de la costa de Sinaloa. El agua de la Corriente de California se observa claramente como un mínimo de salinidad subsuperficial alrededor de 


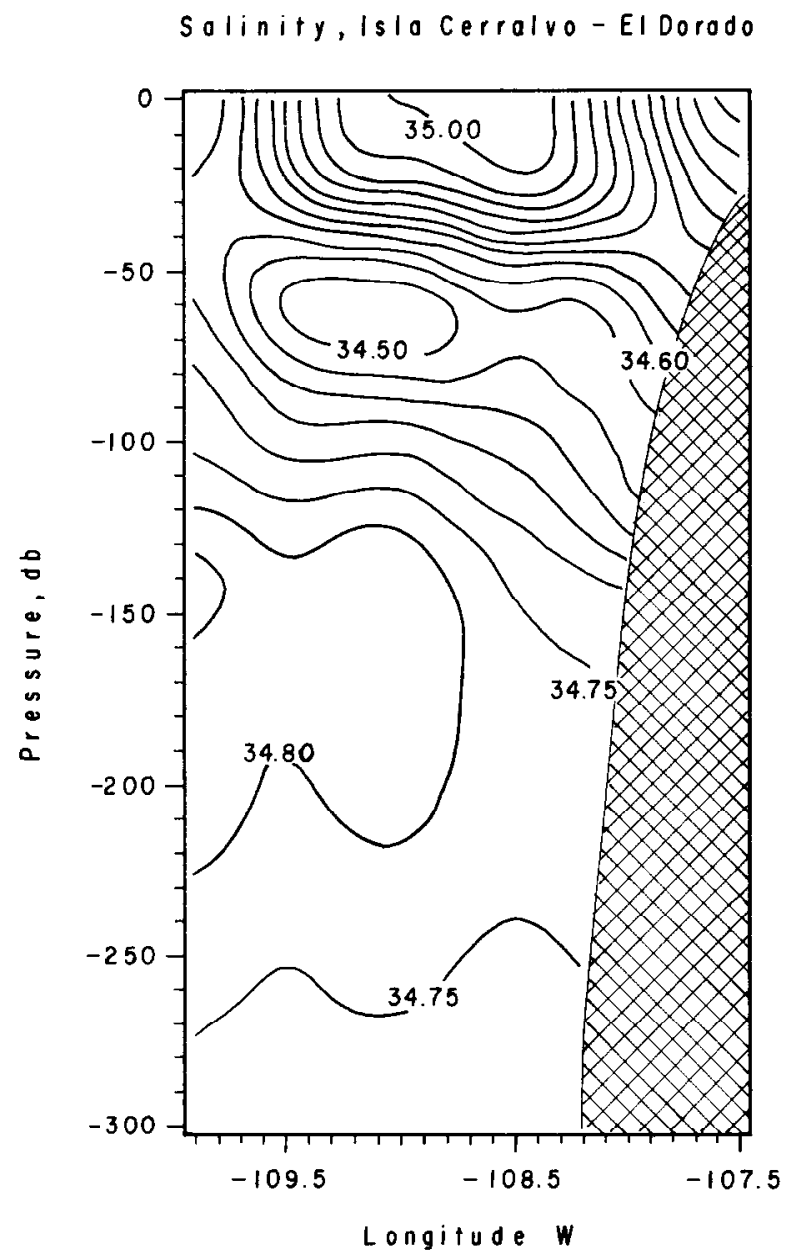

Figure 3. Upper ocean salinity between Isla Cerralvo, Baja California Sur, and El Dorado, Sinaloa, August $12-13,1995$. The contour interval is 0.05 .

Figure 3. Salinidad de la capa superior del océano entre Isla Cerralvo, Baja California Sur, y El Dorado, Sinloa, para el 12 y 13 de agosto de 1995. El intervalo de contorno es 0.05 .

years to form a "mixed El Niño water", which may be subsequently advected into the gulf. The salinity of this water is not given but, based upon standard climatologies (Torres-Orozco, 1993), it should be about $S \sim 34.2-34.5$, much saltier than that observed by FB94.

Mean charts of sea surface salinity (Levitus, 1982) show the $S=33$ isohaline in Panama Basin and north of San Francisco, a significant
$50 \mathrm{~m}$ de profundidad. Se concluye que la tormenta tropical Lester no puede explicar la disminución de salinidad en las aguas superficiales rcportadas en FB94.

Como se menciona en FB94, la fuente más probable de agua de menor salinidad y mayor temperatura en la entrada del golfo es agua superficial tropical (AST). Análisis climatológicos de agua superficial en la entrada del golfo 
distance from the region discussed. Regional synoptic charts of surface salinity are rare, but Roden (1971) shows a narrow tongue of $\mathrm{S}=33.8$ in surface waters about $300 \mathrm{~km}$ to the west of Cabo Corrientes in November 1969. Given this evidence, it strikes us that the pattern of upper ocean salinity shown in FB94 (fig. 5b) is unlikely, principally due to surface salinity $<33$.

Since there are no independent measurements to substantiate these low salts, either with bottle samples on the PALEO VI cruise or in the historical record of hydrographic data, we doubt that the upper layer salts reported by FB94 are correct. Since salinity is derived from conductivity, if we assume that the conductivity was measured correctly and temperature incorrectly, the salinity should increase by $S \sim 0.68$ for cach degree that is subtracted from the temperature. This means that a $2^{\circ} \mathrm{C}$ error in temperature corresponds to an increase in salinity of $S=1.5$, bringing the salinity estimates closer to the climatological mean for these waters, about $\mathrm{S}=34.6$.

There are also inconsistencies in the geostrophic currents (fig. 10a, FB94). The narrow band of southward flow next to Isla Cerralvo appears to be an artifact of the contouring program, since waters at station 8 were denser than those at station 7. A second inconsistency deals with the region of northward flow which occurred at depth between stations 2-5; Ruiz-Loya (1994) shows that this area is much reduced, confined below 500 dbar between stations 3-4, so that southward flow exists over most of the eastern portion of the section. This yields broad anticyclonic flow over most of the section, opposite to that observed in February, except that in February, the shear is much reduced on the Sinaloa side of the section. Thus, the geostrophic outflow is much greater (4.9 Sv) than the inflow in August (Ruiz-Loya, 1994).

\section{CONCLUSION}

Even modern instruments may fail to function properly at sea, a malaise that affects all oceanographers. It appears that this happened to the CTD used on the PALEO VI cruise, so that muestran que la salinidad media en agosto varía de $\mathrm{S}=34.4$ a S $=34.7$ para Sinaloa y Baja California Sur, respectivamente (López-Bojórquez, 1996). Análisis volumétricos (Torres-Orozco, 1993) muestran AST a lo largo de la plataforma de Sinaloa en la Cuenca Pescadero, sobre todo en verano y otono. Se debe tener cuidado en los análisis de las propiedades del agua en la Cuenca Pescadero central y occidental, ya que la mezcla del agua del golfo con la de la Corriente de California puede producir una señal característica de temperatura y salinidad similar a la del AST. Para explicar la disminución en salinidad en la Cuenca de Guaymas, Robles y Marinone (1987) argumentan que el AST se mezcla con agua de la Corriente de California en la entrada del golfo durante años El Niño para producir "agua El Niño modificada", la cual puede ser desplazada postcriormente hacia adentro del golfo. No reportan la salinidad de esta agua, pero con base en climatologías estándar (Torres-Orozco, 1993) debe ser alrededor de $\mathrm{S} \sim 34.2-34.5$, mucha más salada que la observada en FB94.

Gráficas medias de la salinidad de la superficie del mar (Levitus, 1982) muestran que la isohalina $S=33$ se encuentra en la Cuenca de Panamá y al norte de San Francisco, una distancia significativa del área de estudio. Gráficas sinópticas regionales de la salinidad superficial son escasas, pero Roden (1971) señala una lengua angosta de $\mathrm{S}=33.8$ en aguas superficiales a unos $300 \mathrm{~km}$ al oeste de Cabo Corrientes en noviembre de 1969. Con base en esta evidencia, se puede suponer que el patrón de salinidad en la capa superior del océano mostrado en FB94 (fig. 5b) no es probable, principalmente por la salinidad superficial menor que $\mathrm{S}=33$.

Debido a que no hay mediciones independientes para justificar estas sales bajas, ya sea con muestras de botella del crucero PALEO VI o en el registro histórico de datos hidrográficos, es dudable que las sales de la capa superior reportadas en FB94 son correctas. Como la salinidad se deriva de la conductividad, si se supone que la conductividad se midió correctamente $\mathrm{e}$ incorrectamente la temperatura, la salinidad debe incrementarse por $\mathrm{S} \sim 0.68$ por cada grado que se resta a la temperatura. Esto significa que un error en la temperatura de $2^{\circ} \mathrm{C}$ 
near-surface temperatures (salinities) that were too high (low), probably by $2-3^{\circ} \mathrm{C}(\Delta \mathrm{S}=-1.5)$, were recorded. (Note that in these circumstances, the value of ancillary measurements is increased, especially when anomalous conditions seem to occur.) As a consequence, the description of El Niño conditions in the gulf reported by FB94 is not correct.

\section{ACKNOWLEDGEMENTS}

Collection and analysis of CTD data was supported by the Instituto de Investigaciones Oceanológicas, $\mathrm{UABC}$, and by the Instituto de Ciencias del Mar y Limnología, UNAM. C.A. Collins gratefully acknowledges the support of a Fulbright Garcia-Robles fellowship. We thank three anonymous reviewers for comments which significantly improved this paper.

\section{REFERENCES}

Blanco-Betancourt, R., Larios-Castillo, S., GilSilva, E., Mascarenhas, A., Durazo-Arvizu, R. y Collins, C. (1995). Datos hidrográficos del crucero PESCAR 7, agosto 11-21, 1995. Instituto de Investigaciones Oceanológicas, Universidad Autónoma de Baja California, Ensenada, BC, México, 49 pp.

Cole, D.A. and McLain, D.R. (1989). Interannual variability of temperature in the upper layer of the North Pacific eastern boundary region, 1971-1987. NOAA Tech. Memorandum NMFS-SWFC-125, $16 \mathrm{pp}$.

EG\&G Ocean Products (1982). Mark IIIB conductivity, temperature, depth profile underwater unit, operation and maintenance manual. Cataumet, MA 02534, 139 pp.

Fernández-Barajas, M.E., Monreal-Gómez, M.A. and Molina-Cruz, A. (1994). Thermohaline structure and geostrophic flow in the Gulf of California, during 1992. Ciencias Marinas, 20(2): 267-286.

Lavín, M.F. and Organista, S. (1988). Surface heat flux in the northern Gulf of California. J. Geophys. Res., 93: 14033-14038.

Levitus, S. (1982). Climatological atlas of the world ocean. NOAA Professional Paper 13, Rockville, MD, 173 pp. corresponde a un incremento en salinidad de $S=1.5$, haciendo que las estimaciones de salinidad se acerquen a la media climatológica para estas aguas, alrededor de $S=34.6$.

También hay inconsistencias en las corrientes geostróficas (fig. 10a, FB94). La banda angosta de flujo hacia el sur adyacente a la Isla Cerralvo parece ser resultado del programa para hacer mapas de contornos, ya que el agua en la estación 8 era más densa que la de la estación 7 . Otra inconsistencia se encontró en la región de flujo hacia el norte que ocurrió en la profundidad entre las estaciones 2-5; Ruiz-Loya (1994) señala que esta área es muy reducida y confinada debajo de 500 dbar entre las estaciones 3 y 4 , lo que provoca un flujo hacia el sur sobre casi toda la porción este de la sección. Esto resulta en un flujo anticiclónico ancho sobre casi toda la sección, y es lo opuesto a lo observado en febrero, excepto que en febrero, el gradiente lateral es muy reducido en el lado de Sinaloa. Por tanto, el flujo de salida geostrófico es mucho mayor (4.9 Sv) que el flujo de entrada en agosto (Ruiz-Loya, 1994).

\section{CONCLUSIÓN}

Aun los instrumentos modernos pueden fallar en el mar, un problema que afecta a todos los oceanólogos. Parece ser que esto es lo que pasó con el CTD utilizado en el crucero PALEO VI, ya que se registraron temperaturas (salinidades) cercanas a la superficie demasiado altas (bajas), probablemente del orden de $2-3^{\circ} \mathrm{C}$ $(\Delta S=-1.5)$. (Nótese que bajo estas circunstancias, son aún más imortantes las mediciones auxiliares, especialmente cuando se presentan condiciones anómalas.) Por tanto, la descripción de condiciones El Niño en el Golfo de California en FB94 no es correcta.

\section{AGRADECIMIENTOS}

El Instituto de Investigaciones Oceanológicas de la UABC y el Instituto de Ciencias del Mar y Limnología de la UNAM participaron en la recolección y el análisis de los datos del CTD. C.A. Collins agradece el apoyo financiero a través de la beca Fulbright 
López-Bojórquez, J.M. (1996). Hidrografía y dinámica del Pacífico transicional mexicano. Tesis de maestría, Centro de Investigación Científica y de Educación Superior de Ensenada, BC, México, $105 \mathrm{pp}$.

Pudov, V.D. and Holland, G.J. (1994). Typhoons and ocean: results of experimental investigations. BMRC Res. Rep. No. 45, Melbourne, Australia, $50 \mathrm{pp}$.

Robles, J.M. and Marinone, S.G. (1987). Seasonal and interannual thermohaline variability in the Guaymas Basin of the Gulf of California. Cont. Shelf Res., 7: 715-733.

Roden, G.I. (1971). Aspects of the transition zone in the northeastern Pacific. J. Geophys. Res., 76(15): 3462-3475.

Roden, G.I. and Groves, G.W. (1959). Recent oceanographic investigations in the Gulf of California. J. Mar. Res., 18: 10-35.

Roll, H.U. (1965). Physics of the Marine Atmosphere. Academic Press, New York, $426 \mathrm{pp}$.
García-Robles. Se agradecen los comentarios de tres revisores anónimos, los cuales mejoraron el manuscrito.

Traducido al español por Jennifer Davis.

Ruiz-Loya, E.R. (1994). Flujos de calor, agua y sal en la entrada del Golfo de Baja California durante invierno y verano de 1992 . Tesis de licenciatura, Universidad Autónoma de Baja California, Ensenada, BC, México, $40 \mathrm{pp}$.

Sanford, T.B., Black, P.G., Haustein, J.R., Feeney, J.W., Forristall, G.Z and Price, J.F. (1987). Ocean response to a hurricane. Part I: Observations. J. Phys. Ocean., 17: 2065-2083.

Torres-Orozco, E. (1993). Análisis volumétrico de las masas de agua del Golfo de California. Tesis de maestría, Centro de Investigación Científica y de Educación Superior de Ensenada, BC, México, $80 \mathrm{pp}$.

\author{
$\Lambda$ dolfo Molina-Cruz \\ María Adela Monreal-Gómez \\ María Elena Fernández-Barajas \\ Instituto de Ciencias del Mar y Limnología \\ Universidad Nacional Autónoma de México \\ Apartado postal 70-305 \\ 04510 México, DF
}

Nuestra réplica es breve, porque aceptamos como un derecho de los autores de estos comentarios, atraer la atención de la comunidad oceanográfica para poner en duda los valores de las mediciones hidrográficas hechas mediante un CTD Neil Brown, durante el crucero PALEO VI, en agosto de 1992. Después de su observación de datos históricos y relaciones entre temperatura, salinidad, conductividad y densidades regionales, aceptamos cabalmente que es posible que el CTD no haya trabajado
Our reply is brief, because we accept that the authors of these comments have the right to bring to the attention of the oceanographic community and question the values of the hydrographic measurements made with a Neil Brown CTD, during the PALEO VI cruise, in August 1992. After their review of historical data and relationships between temperature, salinity, conductivity and regional densities, we fully accept that the CTD might have malfunctioned or been improperly calibrated 
- estado calibrado correctamente durante el crucero PALEO VI. No obstante, consideramos como una actitud malintencionada, el que nuestra contraparte haga público nuestro trabajo a medias, ya que nosotros mismos, en el trabajo cuestionado (Fernández-Barajas et al., 1994), pusimos en duda la calibración del instrumento (CTD), manifestando, por lo tanto, que las mediciones debian considerarse relativas entre sí. No encontramos razón para que el CTD funcionara en forma distinta entre la superficie y otras profundidades. Tomando en cuenta dicha aclaración, concluimos que durante el tiempo correspondiente al crucero PALEO VI, se desarrolló una capa superior de aproximadamente 20 a $25 \mathrm{~m}$, significativamente más caliente y menos salina que las subsuperficiales, atribuyendo esto al fenómeno oceanográfico El Niño 1992-1993 y a la tormenta tropical Lester; aunque posiblemente no con temperaturas tan altas y salinidades tan bajas como las reportadas en Fernández-Barajas et al., 1994. Actualmente, no hay duda de que el fenómeno El Niño y la tormenta tropical Lester se manifestaron en el Golfo de California en 1992 (ver, por ejemplo, Thunell et al., 1993).

\section{REFERENCIAS}

Fernández-Barajas, M.E., Monreal-Gómez, M.A. y Molina-Cruz, A. (1994). Estructura termohalina y flujo geostrófico, en el Golfo de California, durante 1992. Ciencias Marinas, 20(2): 267-286. during the PALEO VI cruise. However, we do feel that there was ill-intent on their part, since we, ourselves, in the study in question (Fernández-Barajas et al., 1994), queried the calibration of the instrument (CTD), stating that the measurements should be considered relative. We found no reason for the CTD to function differently between the surface and other depths. Therefore, we conclude that during the time corresponding to the PALEO VI cruise, there was a surface layer of approximately 20 to $25 \mathrm{~m}$, significantly hotter and less saline than the subsurface ones, which can be attributed to the 1992-1993 El Niño event and tropical storm Lester; although possibly not with such high temperatures and low salinities as those reported in Fernández-Barajas et al. (1994). There is no doubt that the El Niño event and tropical storm Lester were manifested in the Gulf of California in 1992 (see, for example, Thunell et al., 1993).

English translation by Jennifer Davis.

Thunell, R., Pride, C., Tappa, E. and MüllerKarger, F. (1993). Varve formation in the Gulf of California: insights from time series sediment trap sampling and remote sensing. Quaternary Sci. Rev., 12: 451-464. 